Images $\ln .$.

\title{
An aortoesophageal fistula in an elderly woman
}

\author{
Chien-Chung Fang, ${ }^{1}$ Yuan-Horng Yan ${ }^{2}$ \\ ${ }^{1}$ Division of Gastroenterology, Department of Internal Medicine, Ditmanson Medical Foundation, Chia-Yi Christian Hospital, Chiayi, Taiwan \\ ${ }^{2}$ Department of Medical Research, Ditmanson Medical Foundation Chia-Yi Christian Hospital, Chiayi, Taiwan
}

Correspondence to Dr Yuan-Horng Yan,r92841010@gmail.com

\section{DESCRIPTION}

A 79-year-old woman presented with a case of hypertensive cardiovascular disease and liver cirrhosis. Her medical history of fish bone with oesophageal perforation and mediastinitis was noted. She suffered from sudden onset of haematemesis while brushing teeth and $500 \mathrm{ml}$ fresh blood was vomited. Emergent panendoscopy (PES) showed a vessel with active spurting over $20 \mathrm{~cm}$ from the incisor in the oesophagus. An aortoesophageal fistula (AEF) with active spurting was impressed. Contrast chest CT study in axial (figure 1) and coronal (figure 2) view showed a linear hyperdensity (arrow) and abnormal gas in mediastinum between swollen oesophagus (E) and aortic arch with a small pseudoaneurysm (arrow head). Fish bone penetrated the oesophagus resulting in mediastinitis and mycotic aneurysm of the aorta was considered. Thoracic endovascular aortic repair (TEVAR) was per-

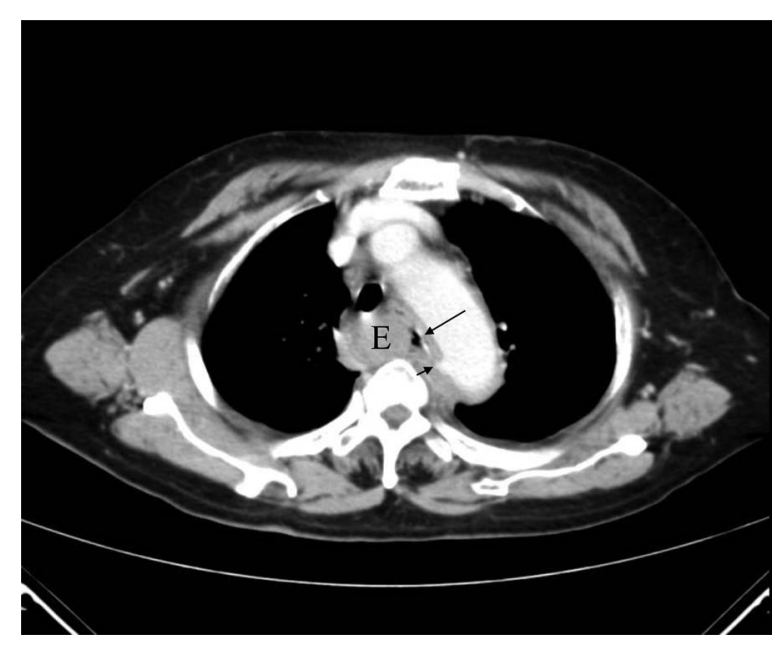

Figure 1 Contrast chest computed tomography (CT) in axial view showed a linear hyperdensity (arrow) and abnormal gas in mediastinum between swollen oesophagus (E) and aortic arch with a small pseudoaneurysm (arrow head).

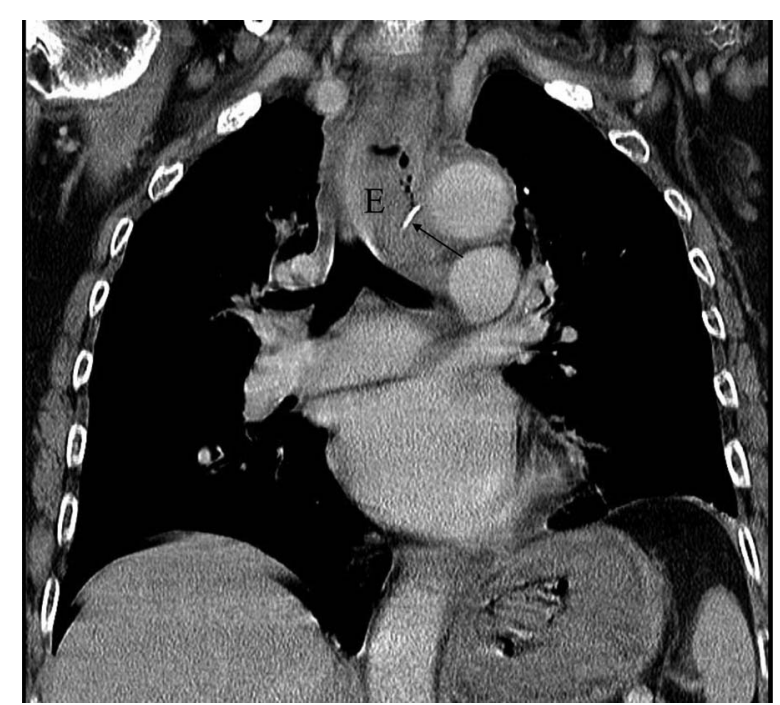

Figure 2 Computed tomography (CT) in coronal view showed a linear hyperdensity (arrow) in mediastinum between oesophagus (E) and aorta.

formed and the fish bone was removed. The patient has survived over 1 year without severe complications.

\section{Learning points}

- A case of aortoesophageal fistula (AEF) caused by a fish bone that had a nice outcome after treatment.

- Contrast CT was a useful tool in detecting AEF.

Competing interests None.

Patient consent Obtained. 


\section{BMJ Case Reports}

Copyright 2012 BMJ Publishing Group. All rights reserved. For permission to reuse any of this content visit http://group.bmj.com/group/rights-licensing/permissions.

BMJ Case Report Fellows may re-use this article for personal use and teaching without any further permission.

Please cite this article as follows (you will need to access the article online to obtain the date of publication).

Fang C-C, Yan Y-H. An aortoesophageal fistula in an elderly woman. BMJ Case Reports 2012;10.1136/bcr-2012-007415, Published XXX

Become a Fellow of BMJ Case Reports today and you can:

- Submit as many cases as you like

- Enjoy fast sympathetic peer review and rapid publication of accepted articles

- Access all the published articles

- Re-use any of the published material for personal use and teaching without further permission

For information on Institutional Fellowships contact consortiasales@bmjgroup.com

Visit casereports.bmi.com for more articles like this and to become a Fellow 